\title{
Maquiavel e os Riscos da Corrupção Política na República
}

\author{
[Machiavelli and the Risks of Political Corruption in the Republic]
}

\section{Vital Francisco Celestino Alves®}

Resumo: Entre os expoentes da tradição republicana, Maquiavel ocupa um lugar de prestígio inquestionável. A sua posição nessa tradição teórica contribuiu indubitavelmente para o resgate da importância e gravidade do problema da corrupção política na república. Em suas obras, Discursos sobre a primeira década de Tito Lívio e História de Florença, é possível verificar uma interessante reflexão do secretário florentino sobre o referido problema. Ambicionando refletir sobre os perigos da corrupção para a república, nesse artigo analisaremos: primeiro, a definição de república apresentada por Maquiavel e sua íntima ligação com a noção de liberdade política e, depois, buscando valorizar e entender, examinaremos os riscos da corrupção política no regime republicano.

Palavras-chave: República, liberdade, corrupção política.

Abstract: Among the exponents of republican tradition, Machiavelli occupies a place of unquestionable prestige. His position in this theoretical tradition has undoubtedly contributed to the recovery of the importance and gravity of the problem of political corruption in the republic. In his works Discourses on the first decade of Titus Livius and Florentine Histories, one can find an interesting reflection of the Florentine secretary on the said problem. Aiming to reflect on the dangers of corruption for the republic, in this article, we shall analyze: first, Machiavelli's definition of the republic and its intimate connection with the notion of political freedom; secondly, in an effort to value and understand, we shall examine the risks of political corruption in the republican regime.

Keywords: Republic, freedom, political corruption.

\section{República: liberdade e conflito}

Analisando os Discursos sobre a
primeira década de Tito Livio'

certifica-se que Maquiavel define a "república" como regime político da liberdade e da virti2? Esse

\footnotetext{
${ }^{*}$ Doutor e Mestre em Filosofia pela Universidade Federal de Goiás (UFG), e Licenciado em Filosofia pela Universidade Católica de Brasília (UCB). Atualmente é professor da Secretaria de Educação do Distrito Federal. E-mail: vitalalves1@gmail.com. ORCID: https://orcid.org/0000-0001-9072-5002.

${ }^{1}$ Daqui por diante vamos nos referir a essa obra apenas como Discursos.

${ }^{2}$ Maquiavel retoma conceitos clássicos como o de virtù e os reelabora com o objetivo de extraí-los do âmbito moral no qual amiúde são inseridos e os inscreve no âmbito da política. Com isso, o diplomata florentino opera uma cisão entre moral e política e elabora um pensamento original tornando a política uma categoria autônoma. Nesse sentido, pode-se dizer que embora se constate na reflexão de Maquiavel a ausência de uma "definição" do
} 
regime é marcado pelo enaltecimento da ação e da participação dos cidadãos na seara pública. Sob a pena maquiaveliana, a questão primordial da ordem republicana gira em torno da importância de se conhecer a realidade política para engendrar meios de gerenciar os conflitos $3^{3}$ e assegurar que eles se expressem como parte da dinâmica política necessária à manutenção da liberdade 4 .

A república também pode ser definida como "o modelo político da liberdade", e para entendermos a acepção de "república" faz-se necessário perscrutar o conceito de "liberdade". Para Maquiavel, a experiência confirma que os povos apenas enriquecem e se tornam poderosos quando vivem em um governo no qual prevalece a liberdade. Em seus termos, "é fácil entender donde provém nos povos essa afeição pela vida livre, porque a experiência mostra que as cidades nunca crescem em domínio nem em riquezas, a não ser quando são livres" (MAQUIAVEL,
2007, p. 186) $)^{5}$ O núcleo duro de uma ordenação republicana, portanto, é a liberdade, e a sua prevalência possibilita que o bem comum seja alcançado. Eis as razões pelas quais o bem comum pode ser percebido nas repúblicas, conforme observa o diplomata florentino:

(...) sem dúvida, esse bem comum só é observado nas repúblicas, porque tudo o que é feito para o seu bem, e mesmo que aquilo que se faça cause dano a um ou outro homem privado, são tantos os que se beneficiam que é possível executar as coisas contra a vontade dos poucos que por elas sejam prejudicados. (MAQUIAVEL, 2007, p. 187). 6

Pode-se afirmar assim que é o bem comum e não o interesse particular que fornece uma base de sus-

conceito de virtù como habitualmente encontramos na tradição filosófica, provavelmente o termo virtù seja um daqueles acerca do qual o secretário florentino mais articula sua abordagem política. Assim, ao empregar o termo virtù ele se refere à capacidade do ator político agir de maneira apropriada no momento adequado, isto é, em política, o ator político dotado de virtù é aquele que é capaz de imprimir mudanças no curso da história e realizar obras admiráveis.

${ }^{3}$ Maquiavel entende que os conflitos fazem parte do jogo político e suprimi-los representaria a dissipação da própria natureza da política. Adiante versaremos mais detalhadamente sobre essa questão.

${ }^{4}$ Seguindo o esclarecimento de Patrícia Aranovich (2007), encontramos no pensamento de Maquiavel duas formas de liberdade: a externa e a interna. Existe liberdade externa quando um principado ou uma república não estão sujeitos a outros estados. A liberdade interna, por sua vez, refere-se à liberdade republicana que pode ser compreendida a partir da ideia de conflito civil. Na análise que será realizada, examinaremos primeiro a liberdade externa e, posteriormente, a liberdade interna.

${ }^{5}$ Discursos, Livro Segundo, Cap. 2.

${ }^{6}$ Discursos, Livro Primeiro, Cap. 4. 
tentação a uma república e tal bem é visto somente nas ordenações republicanas. Para além dessa identificação, o diplomata florentino demonstra a íntima relação entre "república" e "liberdade" ao perscrutar a questão da fundação da república. Observase no primeiro capítulo dos Discursos que Maquiavel inicia sua análise a partir de uma semelhança que reconhece na fundação de Roma, Atenas e Veneza; e refere-se ao fato de que essas repúblicas surgiram livres do domínio de outros povos. Ao examinar as cidades que tiveram o caráter livre em suas fundações, o pensador separa as que se destacam pela contribuição de um notável legislador, presente no momento da fundação, e que conseguiram se conservar por um tempo significativo, como é o caso de Esparta e aquelas que receberam leis aleatoriamente em diversos momentos, devido aos "acontecimentos", como Roma, por exemplo. Algumas cidades, escreve Maquiavel,

receberam leis, em seu princípio ou depois de não muito tempo, de um só homem e de uma só vez - como as leis que foram ditadas por Licurgo aos espartanos - e outras as receberam ao acaso e em várias vezes, segundo os acontecimentos, como ocorreu em Roma. Assim, pode considerar-se feliz a república à qual caiba por sorte um homem tão prudente que lhe dê leis de tal modo ordenadas que seja possível viver com segurança sob tais leis, sem precisar corrigilas. (MAQUIAVEL, 2007, p.12-13). 7

Apesar de reconhecer o caráter livre das duas cidades e correlacioná-las, parece-nos que o interesse maior de Maquiavel refere-se à segunda cidade, pois são as desse feitio, em sua visão, que instigam nossa compreensão sobre a relevância da figura do legislador e, concomitantemente, acerca da implantação das leis, visto que desprovida já em sua fundação de um alicerce seguro, tais cidades evidenciam, por meio das fases de sua construção, os percalços que envolvem a instrução processual de um corpo político.

Atesta-se que, na perspectiva maquiaveliana, a fundação de uma cidade pressupõe um deline-

\footnotetext{
${ }^{7}$ Discursos, Livro Primeiro, Cap. 2.
} 
amento que proporcione aos cidadãos um crescimento numérico e forneça à população estrutura nos prováveis momentos de guerra e que salvaguarde seu lugar na vida política institucional. As discussões ruidosas e os conflitos associados à própria constituição romana, por mais inconvenientes que produzissem, foram decisivas para resguardar a liberdade do povo. Mas, por que exatamente para Maquiavel as discussões ruidosas e os conflitos políticos foram decisivos para salvaguardar a liberdade do povo? Porque na percepção do secretário florentino,

\section{(...) se deve dar a guarda} de uma coisa àqueles que têm menos desejo de usurpá-la (...). E sem dúvida, se considerarmos o objetivo dos nobres e o dos plebeus, veremos naqueles grandes o desejo de não serem dominados e, por conseguinte, maior vontade de viver livres, visto que podem ter menos esperança de usurpar a liberdade do que os grandes; de tal modo que, sendo os populares encarregados da guarda de uma liberdade, é razoável que tenham mais zelo e que, não podendo eles mesmos apoderar-se dela, não permitirão que outros se apoderem. (MAQUIAVEL, 2007, p. 24)

Verifica-se, em face desse trecho que o secretário florentino sai em defesa de Roma muito mais pelo viver político do que em função da grandeza ou expansão. Assim a ordem republicana deve ter como prioridade a conservação do viver político e tornar o cidadão apto para lutar, se necessário, em nome desse modo de viver. A ampliação territorial e a guerra, contudo, não podem estar à frente da liberdade e da boa ordenação. O que se vê em Maquiavel é que a cidade deve estar em condições de lutar para proteger a liberdade e que os cidadãos e governantes devem estar preparados para lutarem com o objetivo de garantir a liberdade.

O preço de se ter uma cidade que seja capaz de lutar, se neces-

\footnotetext{
${ }^{8}$ Discursos, Livro Primeiro, Cap. 5.

${ }^{9}$ Doravante, nos deteremos estritamente na avaliação da "liberdade interna". A saber, para se compreender essa liberdade será vital investigar a questão dos humores mediante o conflito entre o povo e os grandes. Posto que, no pensamento de Maquiavel, esse conflito se configura na origem da liberdade e da grandeza de Roma. É interessante assinalar, considerando a linha interpretativa de Patrícia F. Aranovich (2007), que a vida republicana assim como o seu avesso (a servidão) produzem um hábito nos povos. As repúblicas são marcadas pela estima à liberdade, afeição que as conduzem a perseverarem em conservá-la no seio da cidade (internamente) e, ao mesmo tempo, em digladiarem bravamente para manter a liberdade externa.
} 
sário, e expandir, é o conflitd 9 civil. A cidade então deve ter habilidade para resolver conflitos. Nesse sentido, os tumultos tornaram Roma mais vigorosa do que as frágeis repúblicas de Esparta e Veneza ${ }^{10}$ Maquiavel foi preconizador da cidade livre, composta de agentes políticos ${ }^{11}$ dotados de virtù. Ele mostrou para os seus contemporâneos que as discórdias constituem um traço da vida na república e argumentou que o viver político não está especificamente vinculado ao consentimento. Seguindo a reflexão maquiaveliana, comprova-se que a política ainda é a arte da cidade. E ela deve ser fundamentada e mantida em um ambiente inseguro no qual a liberdade apenas pode ser avalizada à custa do conflito.

Ao justificar sua predileção por Roma, equiparada à Esparta e Veneza, Maquiavel, explicita, simultaneamente, o estreito liame entre conflito e liberdade 12 e o ilustra a partir da questão dos desejos opostos nas cidades. Ele aborda essa questão no capítulo IX de $O$ Príncipe quando analisa as formas de se chegar ao poder, sejam elas "pelo favor do povo ou pelo favor dos poderosos". Afirma ele:

(...) em todas as cidades se encontram estas duas tendências diversas e isto nasce do fato de que o povo não deseja ser governado nem oprimido pelos grandes, e estes desejam governar e oprimir o povo. Destes dois apetites nasce nas cidades um destes três efeitos: principado, liberdade, desordem. (MAQUIAVEL, p. $67,1996) \cdot 13$

Que entendimento se pode extrair a partir da leitura desse extrato? Julgamos que é possível sublinhar três pontos centrais: ${ }^{14}$ o primeiro, Maquiavel reconhece dois desejos divergentes, oprimir e não ser oprimido. O segundo, a maneira como a ordem política pode ser ordenada, isto é, principado e liberdade. O terceiro, a possibilidade do conflito entre desejos díspares produzir a desordem. Observa-se que a luta pela conquista do poder gera uma tensão que aparen-

\footnotetext{
${ }^{10}$ Especialmente nos capítulos 5 e 6, do Livro Primeiro, dos Discursos, Maquiavel apresenta um significativo cotejamento entre as repúblicas de Esparta e Veneza em comparação a Roma. Não acreditamos ser necessário explicitar os aspectos desse cotejamento. Pois o que nos interessa aqui é lançarmos luzes sobre tão somente a ordenação republicana de Roma.

${ }^{11}$ Dispostos a defenderem a liberdade.

${ }^{12}$ Para um aprofundamento sugere-se a leitura de Maquiavel, de Newton Bignotto (2003).

${ }^{13}$ O Principe, Cap. IX.

${ }^{14}$ Como destacam Bignotto (1991), Adverse (2007) e Ames (2010) com os quais estamos em conformidade.
} 
temente não tem solução, pois os desejos dos grupos, assim como eles propriamente ditos, são antagônicos. Logo, saciar o desejo de um é sacrificar o do outro. Essa leitura também ressoa nos Discursos, quando o autor florentino declara que:

\section{(...) em toda república há} dois humores diferentes, $\mathrm{o}$ do povo, e o dos grandes, e que todas as leis que se fazem em favor da liberdade nascem da desunião deles, como facilmente se pode ver que ocorreu em Roma (MAQUIAVEL, p. 22, 2007)

Constata-se assim que o conflito ${ }^{16}$ entre grupos antagônicos no cerne da república não representa um perigo para sua sobrevivência, mas, sim, forma o eixo de sustentação da liberdade. Atesta-se, paralelamente, que a passagem dos Discursos está em plena consonância com a de $O$ Príncipe. Vale notar, contudo, que em sua segunda obra o diplomata florentino associa as divergências na sociedade à liberdade e também à lei. Assim, uma república é livre, aos olhos maquiavelianos, quando tem a habilidade de fornecer respostas institucionais - como no caso de Roma - para os conflitos que têm sua origem nas divergências de desejos.

Maquiavel compreende a liberdade como um efeito dos conflitos políticos e, ao mesmo tempo, pulveriza o viés estritamente formal da lei. A saber, a lei é reconhecida por ele como o reflexo das divergências sociais que se direcionam para o bem comum, e, em outras palavras, ela é o resultado histórico dos confrontos políticos. Novamente aqui Maquiavel tem em vista Roma, que fabricou instituições políticas e leis imprescindíveis para sua liberdade durante séculos, ao invés de serem erigidas pela sabedoria de um legislador, como no caso de Esparta. A audácia de Maquiavel não cessa com essa premissa, ele advoga que a lei não é fruto da conciliação entre os desejos, diferentemente, ela tem sua gênese no desfecho do conflito permanente entre os desejos aos quais não podem se sobressair aos seus opostos, pois se configura em uma ameaça à vida da república.

A liberdade ocupa o posto de valor decisivo em um regime re-

\footnotetext{
${ }^{15}$ Discursos, Livro Primeiro, Cap. 4.

${ }^{16}$ Para um aprofundamento, sugere-se as seguintes leituras: Maquiavel, a república e o desejo de liberdade. Adverse, H., em Trans/Form/Ação. v. 30, 2007. E, Maquiavel versus Rousseau: as divisões sociais e seu papel em uma república bem ordenada. Moscateli, R., em Trans/Form/Ação. v. 38, 2015.
} 
publicano e sua defesa é fundamental para que as obras humanas perdurem. Acontece que amiúde elas correm o risco de serem solapadas, não só pelo elemento temporal, mas também pela natureza dos homensi7, Esse cenário de perplexidade apresentado por Maquiavel evidencia em seu interior também um desassossego acerca de um problema maior na república e que vamos analisar a seguir: a corrupção política. Então, indagamos: quais são as causas que possibilitam o advento da corrupção política na república segundo a teoria de Maquiavel?

\section{Os riscos da corrupção política}

O problema da corrupção ${ }^{18}$ política foi abordado por Maquiavel levemente em $O$ Príncipe, e adquiriu vigor nos Discursos, ressurgindo com recrudescimento em História de Florença. Vamos nos deter brevemente nas duas últimas obras mencionadas. Nos Discursos comprova-se que o secretário florentino se dedica, com

\footnotetext{
${ }^{17}$ Apesar de notarmos demasiadas considerações e contundentes assertivas sobre a natureza humana em Maquiavel, não vemos no seu pensamento a construção de uma teoria antropológica. Ele não nos oferece uma explicação razoável sobre o que compreende por "natureza humana", todavia, é notório que o diplomata florentino considera que a natureza do homem é ambiciosa e é marcada pelo desejo, logo, como vimos, não é possível impedir o conflito entre os homens e os grupos. Pois o conflito é como um motor que move a ação humana e faz os homens se confrontarem por necessidade ou ambição.

${ }^{18}$ A redescoberta do tema da corrupção na Renascença foi realizada pelos humanistas cívicos. A partir deles, a noção de corrupção é herdada e transformada. A tradição humanista republicana dos séculos XIV e XV recupera o conceito de corrupção aludindo a Roma, valorizando elementos fundamentais da vida civil e se desligando das singularidades jurídico-formais do exercício do governo às quais o aristotelismo preconizava. Não vemos uma preocupação entre os humanistas com as formas do exercício do poder, mas sim com os valores que regulam a ação do corpo político e formam os princípios elementares que ordenam a república. Em termos genéricos, o pensamento humanista compreende a corrupção como a falta de espírito público no centro do corpo político. Assim, eles relacionam a corrupção com a concepção de decoro, no sentido moral, e com a noção de ruína, no que diz respeito à comunidade política. Se os humanistas cívicos recuperaram o problema da corrupção, Maquiavel, segundo Quentin Skinner (1996), foi o primeiro autor do Renascimento a analisar com profundidade o papel da corrupção política na república e a exprimir um olhar mais perspicaz acerca desse problema. Permitindo assim que o conceito de corrupção ganhasse força e passasse a desempenhar uma função estruturante em seu pensamento político. Maquiavel apresenta um conceito intrincado, uma vez que liga a concepção de corrupção à ideia de uma lei natural e universal de degenerescência referente a todas as formas da sociedade política se organizar.

${ }^{19}$ Para Helton Adverse (2012), Maquiavel apresenta o problema da corrupção preliminarmente como um fenômeno de cunho cosmológico capaz de atingir tudo o que é vivo; assim, o pensador de Florença torna a finitude uma certeza irrefutável reservada a todas as naturezas particulares e constituições políticas. Almejando explicar o fenômeno da corrupção, Maquiavel emprega as noções de forma e matéria, concebendo as leis e ordenações inerentes à forma, e a figura do legislador como alguém que institui a lei e busca instaurar uma forma à matéria do corpo político que o compõe. Nesse sentido, Adverse sustenta que, para Maquiavel, quando uma república é fundada, pode, concomitantemente, sofrer, em sua matéria, uma desordem paulatina e natural em decorrência das adversidades do tempo. Quanto à forma que modela a matéria, ela pode ter qualidade ou ser destituída desta. Todavia, desconsiderando essa particularidade da forma, a matéria se inclina naturalmente ao desalinho, a contradizer a forma, e a isso Maquiavel denomina de "corrupção". O comentador acrescenta também que em Maquiavel a corrupção pode ser provocada por condutas inapropriadas à ordem política. A corrupção existe não necessariamente em decorrência do fato das ordenações terem se corrompido, mas também a despeito da realidade passar por vicissitudes que a modificam de tal maneira que ela deixa de corresponder às exigências da matéria. A saber, quando se vê desqualificada para combater os costumes perniciosos e as ganâncias. Como resultado, ao incentivar a desarmonia entre forma e matéria são justamente os costumes prejudiciais que passam a ditar as leis produzindo um arcabouço a eles conveniente. Isto posto, demarcamos que o nosso objetivo aqui é analisar a corrupção política, suas causas,
} 
afinco, a solidificar uma reflexão sobre o tema da corrupção $0^{19}$ na república, nos capítulos 16, 17 e 18 do Livro primeiro. É necessário reportar que nos capítulos predecessores ele havia se preocupado em defender a hipótese - considerando o regime político romano - de que a fundação da liberdade em uma república encontra-se intimamente associada à boa conduta dos desejos que protagonizam conflitos ${ }^{20}$ e alicerçam a vida política.

Deve-se lembrar que Maquiavel, no quarto capítulo da referida obra, trata da questão dos humores marcados pelos desejos heterogêneos: o de dominar e o de não ser dominado, e argumenta que o surgimento de leis e instituições políticas foi crucial para que a república romana ganhasse força e se tornasse saudável. $\mathrm{Na}$ instauração de tais ordenações, o povo desponta como defensor da liberdade ${ }^{21}$, visto que seu desejo tem como principal escopo a preservação da mesma. Desse modo, pode-se dizer que a subsistência de uma vida política livre ${ }^{22}$ pressupõe uma frequente diligência a ser desempenhada pelo povo visando conter a avidez dos grandes, os quais são dotados de um incansável desejo de dominação. Por outro lado, para o diplomata florentino, a república também não pode subsistir se o desejo do povd ${ }^{23}$ não for contido pelos grandes, pois a consumação desse desejo de não ser oprimido nem governado resultaria na licenciosidade ao invés de na liberdade.

A função decisiva que Maquiavel confere ao povo na república nos orienta, ainda que precipitadamente, a ver a corrupção como um problema que se refere, em especial, ao povo, acima de tudo porque é ele, o povo, que tem responsabilidade de resguardar a liberdade. No entanto, avaliamos que a corrupção pode acometer qualquer um dos agentes políticos de uma república 24 , e todos ao mesmo tempo. Pode haver situações nas quais a corrupção con-

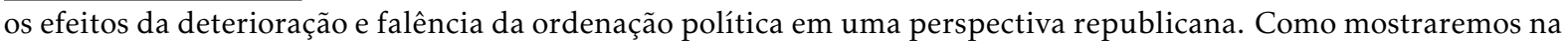
sequência.

${ }^{20}$ Ao tratar dos riscos da corrupção política em Maquiavel, pretende-se articular o fenômeno da corrupção com o tema dos conflitos políticos entre os grandes e o povo. Almejamos demonstrar - a partir dos conflitos políticos como os meios ordinários da república vão se tornando ineficientes para administrar esses conflitos, abrindo então margem para os meios extraordinários que solapam a vida política.

${ }^{21}$ Como destacamos no tópico anterior.

${ }^{22}$ É interessante ressaltar que, para Maquiavel, o papel de guardião da liberdade que o povo desempenha não é uma característica do regime republicano em geral, mas do tipo de república exemplificado por Roma, ou seja, regida pelo governo misto. No outro tipo - o da república que se mantém em seu próprio território e que tem em Veneza e Esparta seus principais protótipos -, a guarda da liberdade coube aos nobres.

${ }^{23}$ Seguiremos aqui a vereda interpretativa percorrida por Helton Adverse (2012).

${ }^{24}$ Leia-se o povo, os grandes ou o príncipe.
} 
tamina o príncipe, enquanto o povo permanece saudável. Em outras circunstâncias, quando todo o corpo político é infectado, a possibilidade de retomar a saúde tornase mínima.

Em sua obra História de Florença, Maquiavel não louva o renascimento da Antiguidade em Florença, tampouco tece elogio à cidade. Em contrapartida, ele narra a decadência, a corrupção e a queda de sua cidade natal. Além disso, mostra nesse livro que a corrupção não se restringe à sua cidade; o autor florentino sustenta a tese platônica-polibiana ${ }^{25}$ que relaciona o corpo político com o corpo humano, isto é, compara e aproxima os dois organismos. Compreender o fenômeno da corrupção política requer discorrer sobre a sua relação com a liberdade. Esta só pode ser concebida quando uma república é bemordenada. Julga-se que a liberdade, aos olhos de Maquiavel, não pode ser encontrada em qualquer espécie de ordenação, existe uma ordenação peculiar e hábil o suficiente para facultar ao conflito a produção da liberdade.

Trata-se de uma ordenação histórica e conceitualmente estabe- lecida por Maquiavel. O modelo tomado como referência é a ordenação romana e o governo misto. O que torna essa ordenação singular e possibilita ao povo infundir leis para a liberdade é o fato de a república ter a expansão como característica. Uma ordenação nesses moldes pressupõe a entrada irrestrita de estrangeiros na cidade e o emprego do povo no exército, o que, consequentemente, o torna numeroso, robusto e fortifica o seu desejo. A liberdade não se configura em um anseio, mas, sim, em um fundamento medular no modelo republicano, e ela se encontra no centro da teoria política de Maquiavel não como uma escolha, mas como necessidade. Uma condição sine qua non para a república.

E a maior ameaça à liberdade é a corrupção, sobretudo quando ela afeta o tecido social. Quando o povo até então não se corrompeu ${ }^{26}$, ainda é possível a ordenação política restaurar a sua liberdade tomando medidas contra os governantes ineficientes. Não obstante, provavelmente, no momento em que todo o corpo está comprometido pela corrupção, a ordenação política não terá mais

\footnotetext{
${ }^{25}$ Segundo essa tese, os governos se inclinam naturalmente e infalivelmente à corrupção, uma vez que defende que todos os corpos políticos na mesma medida que os corpos naturais estão sujeitos a um processo degenerativo.

${ }^{26} \mathrm{Na}$ análise de Adverse (2012), "um povo que tem êxito em suas conquistas" acaba tornando-se relaxado e vulnerável à degradação. Assim, a corrupção repousa inicialmente nos costumes do povo que, ao se corromperem, impedem as boas ordenações de reverberarem bons resultados e leis eficientes.
} 
a capacidade de recobrar a liberdade perdida 27 . A corrupção na república é exatamente o reverso da liberdade, constatada no avançado déficit da ordenação, presente em face das investidas particulares que almejam dominá-la.

Ao nos apresentar a História de Florença, Maquiavel demonstra que o percurso da cidade é o da corrupção, compreendida como contínuo desgaste das ordenações. Porém, em oposição à corrupção tida como um fenômeno natural que corrói até mesmo aquelas repúblicas bem-ordenadas, a corrupção que atingiu Florença, de acordo com Maquiavel, foi o resultado de uma ordenação ineficaz 28 . Nela, a nobreza teve seu espírito corajoso extirpado, assim como sua valentia guerreira, e o povo se confinou na condescendência. Ademais, na História de Florença testemunhamos Maquiavel desvendar, por meio do seu relato, o encadeamento da corrupção da república de sua cidade, isto é, a destruição do modo de vida livre.

Em sua reflexão tocante à corrupção política, Maquiavel também narra o tradicional percurso pelo qual as boas formas de governo se corrompem e se transformam em formas degeneradas. Ele sai em defesa da forma de governo mista ${ }^{29}$ como a melhor condição de estipular a força da lei capaz de preservar a república e combinar os poderes ao longo do tempo. Somente com esse arranjo político, acredita Maquiavel, tem-se uma república consistente.

Mediante a análise acerca do problema da corrupção, observamos também que a virtù é uma condição imprescindível para manter a república. A cidade que consegue acautelar frequentemente a virtù de seus cidadãos conserva o modo de vida livre. Nota-se, pelo processo detalhado por Maquiavel em relação a Roma, nos Discursos, e no que diz respeito à sua cidade natal, em História de Florença, que a partir do momento em que os grandes passam

\footnotetext{
${ }^{27}$ Convém registrar, todavia, que no final do capítulo 18 da primeira parte dos Discursos, Maquiavel cogita a possibilidade de que a república corrompidíssima seja reformada pela intervenção contundente de um príncipe capaz de usar meios extraordinários para reconduzir o Estado à ordem. Apesar de raro o aparecimento de homens assim, não seria impossível. Maquiavel escreve que embora existam várias dificuldades, e amiúde impossibilidades de em cidades acometidas pela corrupção serem mantidas ou se criar uma república, "em se precisando criar ou manter uma, seria necessário, antes, reduzi-la ao estado régio do que ao estado popular; para que os homens insolentes que não pudessem ser corrigidos pelas leis fossem de algum modo freados por uma autoridade quase régia. E torná-los bons por outros meios seria empresa crudelíssima ou de todo impossível” (MAQUIAVEL, 2007, p.76).

${ }^{28}$ Diferentemente de Roma, que conseguiu guiar de maneira salutar os conflitos políticos, tornando-a uma ordenação republicana vigorosa, em Florença a inabilidade de orientar os conflitos políticos enfraqueceu a vida livre e vertiginosamente a conduziu à corrupção e ao declínio.

${ }^{29}$ Ainda que também não acredite na imortalidade dessa forma de governo.

${ }^{30}$ Para Maquiavel, a saúde de uma ordenação política encontra-se no equilíbrio entre os humores dos grandes e do povo. Vale reforçar que "o humor do povo é não ser oprimido pelos grandes". Desse modo, quando, em um
} 
a elaborar as leis com exclusividade ${ }^{30}$, sua autoridade na ordem política se tornará mais forte e o interesse dessa parte - peculiar à república - prevalecerá sobre o do povo. Nesse caso, a corrupção política pode ser reconhecida como o distanciamento da virti ${ }^{31}$, da vida livre e, por consequência, com ênfase na desigualdade. Destarte, segundo o secretário florentino, "a corrupção e a pouca aptidão à vida livre provém de uma desigualdade ${ }^{32}$ existente na cidade". (MAQUIAVEL, 2007, p. 71)

No domínio da corrupção política sobre a virtù, confirma-se uma possível relação entre a desigualdade e a corrupção política. Mas em que consiste essa desigualdade? O significado dessa desigualdade é o que se buscará esclarecer. Avançando a discussão acerca dessa provável relação, notam-se alguns obstáculos interpretativos que até o presente momento ainda não havíamos nos deparado. Ao considerarmos a figura do povo - e, assim como dos conflitos políticos na cidade, surgem dos dois humores elementares -, constata-se que a causa pre- ponderante refere-se ao "desejo dos grandes de governar e oprimir o povo e o do povo em não ser oprimido pelos grandes". No entanto, a despeito da antinomia de tais desejos até o momento não nos foi possível asseverar que o problema da desigualdade social - baseada em elementos econômicos ou políticos - se apresentava como algo vigente. Desse modo, dois pontos podem ser destacados: o primeiro concernente à existência e relevância da desigualdade no esteio dos conflitos políticos, e, o segundo, acerca da questão da natureza dessa desigualdade, isto é, como ela se situa especificamente na reflexão de Maquiavel, no campo econômico, político ou em ambos.

Ambicionando examinar a questão da desigualdade sob a visão do secretário florentino, podemos reportar ao trecho citado na página anterior referente à desigualdade e que foi extraído do final do capítulo 17, do Livro I, dos Discursos, intitulado Um povo corrompido que se torna livre com enorme dificuldade se mantém livre. O trecho supracitado rever-

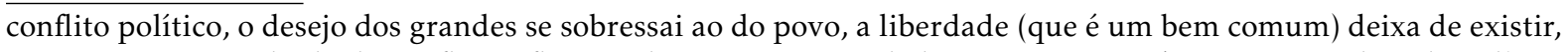
uma vez que o resultado do conflito reflete no depauperamento do bem comum que é proveniente da vida política livre.

${ }^{31}$ Por intermédios dos estudos de Newton Bignotto (2003), certifica-se que quando a corrupção atinge o patamar da universalidade na república ela instala obstáculos para a liberdade que, nem mesmo os atores políticos mais hábeis e detentores de virtù são capazes de superá-los.

${ }^{32}$ Em outras palavras, em uma desarmonia gerada a partir do conflito político ao invés do favorável equilíbrio.

${ }^{33}$ Discursos, Livro primeiro, cap. 17.
} 
bera, por um lado, na correlação desigualdade e corrupção, e, por outro lado, entre igualdade e república. Na interpretação de Gennaro Sasso (1980), os dois congêneres mencionados transpassam a elucubração maquiaveliana sobre a corrupção, em especial à corrupção do povo. Por essa linha interpretativa, julga-se que ao refletirmos sobre a corrupção do povo, ao mesmo tempo se atesta a supressão do equilíbrio e da proporção existente na ordenação republicana. O aprofundamento de uma desigualdade ou a disparidade referente a direitos políticos se inscrevem no rol dos fatores responsáveis pelo declínio dos valores cívicos de um povo 34 .

Em vista disso, no mesmo capítulo, Maquiavel demonstra também que quando um pequeno número de cidadãos livres tem o poder de deliberar sem que haja nenhum tipo de pressão do povo, inevitavelmente deliberará visando seu próprio benefício. As decisões tomadas nesses contextos enrobustecem o poder de tais cidadãos, seja político - cerceando o acesso à possibilidade de tomada de decisão dos outros partícipes da ordem política; seja econômico, extraindo vantagens pessoais dos negócios do Estado. Com efeito, a tendência do alargamento da desigualdade política, pode repercutir também em uma concentração de poder econômico 35 .

A questão da desigualdade política na constelação das ideias republicanas de Maquiavel emerge em função da perscrutação sobre os humores, precisamente devido a ambição ${ }^{36}$ do pequeno número de poderosos. A existência desse desequilíbrio do poder político ressoa na necessidade de se estabelecer um novo equilíbrio do poder devido aos grupos ou pelo menos refrear o descomedimento de ambição dos grandes, pois estes se configuram em uma das principais causas da corrupção. O entendimento de que a desproporcionalidade dos desejos políticos se apresenta como um motivo da cor-

\footnotetext{
${ }^{34}$ No que se refere à relação entre desigualdade e corrupção, tomamos como suporte interpretativo a análise oferecida por José Antônio Martins (2007).

${ }^{35}$ Como ressaltou José Antônio Martins, com quem estamos em plena conformidade, não identificamos na reflexão de Maquiavel qualquer passagem em que a igualdade econômica se inscreva como um pressuposto histórico ou mesmo um objetivo a ser granjeado para a realização da felicidade da cidade. O que parece ficar claro é que o autor florentino desenvolve seu pensamento considerando que existe uma desigualdade econômica tangível, todavia isso não deve ser um imbróglio e tampouco afetar as decisões políticas. Ou ainda observando por outro enfoque, em vista da desigualdade política, o problema não tem a sua origem na desigualdade econômica. Em Maquiavel, o problema da desigualdade econômica não se situa acima do problema mais grave que é a desigualdade política.

${ }^{36}$ No capítulo 37, do Livro I, dos Discursos, Maquiavel acusa a ambição da plebe como responsável pelos problemas ligados à Lei Agrária e que acabaram conduzindo à queda da república. No início do livro 3 da História de Florença, o autor também mostra que o desejo do povo de sua cidade natal era "insolente e injusto", pois ele não queria dividir o poder com a nobreza, levando ao acirramento aos conflitos da república, os quais produziram lutas partidárias com inúmeras mortes e exílios.
} 
rupção da cidade, possivelmente nos permite sustentar que a corrupção das ordens políticas brota, entre outras causas, da corrupção da matéria ${ }^{37}$, sobretudo no que se refere à ambição dos poderosos que assenhoram do poder político na cidade 38 .

\section{Considerações finais}

Tendo em vista a análise realizada, cumpre ainda examinar a seguinte questão: o que podemos depreender da reflexão fomentada por Maquiavel sobre os riscos da corrupção política na república? Em nossa compreensão, pode-se afirmar que, de maneira contumaz, Maquiavel emprega o termo "corrupção" à incapacidade de aplicarem-se esforços na ação política e aos desvios das instituições políticas. A corrupção, pelo prisma de Maquiavel, não é um fenômeno progressivamente uniforme. Ela está presente de maneira ininterrupta, vai se alastrando por todas as partes da sociedade, atingindo espaços ímpares, as classes sociais e o governo, até penetrar nas entranhas do núcleo da ordenação republicana. Ao se apossar do povo como um todo, ele perderá a capacidade de viver em consonância com a liberdade. A corrupção representa a usurpação e a ruína da liberdade ${ }^{39}$. E ao arruinar a liberdade, fatalmente, a república depaupera.

O secretário florentino confere a responsabilidade pela proliferação da corrupção aos próprios homens, que são incapazes de se sobressaírem face às suas próprias limitações ${ }^{40}$. A corrupção originase, assim, na indiferença do cidadão no tocante aos negócios da república. Mais do que ser prejudicial à vida pública por inscrever a ordem republicana em constantes crises que realçam pontualmente o desinteresse do cidadão, a corrupção também é perniciosa porque ocasiona um período de apatia e perturbações que aguça e torna essa prática corriqueira na república. Se Maquiavel deposita a responsabilidade, no que tange à corrupção, às limitações humanas, apesar de oferecer uma reflexão política que se pretenda útil aos governantes e aos cidadãos, a filosofia em si não é colocada por ele como protagonista para guiar

\footnotetext{
${ }^{37}$ Como já foi dito, Helton Adverse nos fornece um importante apoio para compreender esse aspecto na reflexão maquiavelianas sobre a corrupção.

${ }^{38}$ Para um aprofundamento no exame do problema da "cidade corrompida" no pensamento de Maquiavel, recomendamos a seguinte leitura: Os fundamentos da República e sua corrupção nos Discursos de Maquiavel, de José Antônio Martins (2007).

${ }^{39}$ Entendida, especialmente, como a força pública da instituição política.

${ }^{40}$ Como bem destacou Bignotto (1991).
} 
os homens na vida política. Ao reverso, recorrendo ao livro $7 \mathrm{da}$ História de Florença, constata-se que o autor florentino descreve as letras e a filosofia como um tipo de ócio perigoso para as cidades bem ordenadas, posto que ele pode corromper a fortaleza dos ânimos guerreiros necessários à preserva- ção da pátria. Com o objetivo de ilustrar essa ideia, Maquiavel cita o episódio no qual Catão, o censor, se posicionou firmemente contra a presença dos filósofos gregos em Roma, pois viu a admiração que eles suscitavam nos jovens e quis prevenir o mal que esse "honesto ócio" poderia trazer à república.

\section{Referências}

ADVERSE, H. Maquiavel. In: Corrupção - Ensaios e Críticas. Org. Avritzer, L., Bignotto, N., Guimarães, J. , Starling, M.M. H. Belo Horizonte: Ed. UFMG, 2012.

- A matriz italiana. In: Matrizes do republicanismo. Org. Bignotto, N. Belo Horizonte: Ed. UFMG, 2013.

. Maquiavel, a república e o desejo de liberdade. Trans/Form/Ação. Marília - SP: Ed. UNESP, v. 30, 2007.

AMES, José Luiz. A lógica do heterogêneo e a liberdade republicana em Maquiavel. Org. Martins, J. A. In: Republicanismo e Democracia. Ed. UEM, 2010.

ARANHA, M.L.A. Maquiavel: a lógica da força. São Paulo: Moderna, 2006.

BARON, Hans. The crisis of the early italian renaissance. New Jersey: Princeton University Press, 1966.

BIGNOTTO, Newton. Maquiavel republicano. São Paulo: Edições Loyola, 1991.

. Maquiavel. Rio de Janeiro: Zahar, 2003.

GIBBON, Edward. Declínio e queda do império romano. São Paulo: Companhia de Bolso, 2014.

LEFORT, Claude. Le travail de l'oeuvre Machiavel. Paris: Gallimard, 1972.

MAQUIAVEL, N. Discurso sobre a primeira década de Tito Livio. São Paulo: Martins Fontes, 2007.

. História de Florença. São Paulo: Martins Fontes, 2007.

. O Príncipe. São Paulo: Nova Cultural, 1997. (Os Pensado-

res). 
MARTINS, José Antônio. Os fundamentos da República e sua corrupção nos Discursos de Maquiavel. (Tese de doutorado). USP, 2007.

MOSCATELI, Renato. Maquiavel versus Rousseau: as divisões sociais e seu papel em uma república bem ordenada. Trans/Form/Ação. Marília: Ed. UNESP, Marília, V.. 38, 2015.

PLATÃO. A república. São Paulo: Nova Cultural, 1997. (Os Pensadores).

POCOCK, J.G.A. The Machiavellian moment. New Jersey: Princeton University Press, 1975.

POLÍBIO. História. Brasília: UnB, 1985.

SANTOS, Rui B. de Carvalho. Para compreender Maquiavel. CampinasSP: PHI Ltda., 2013.

SASSO, G. Niccolò Machiavelli, storia del suo pensiero politico. Bologna: II Mulino, 1980.

SHUMER, S. Machiavelli: Republican Politics and its Corruption. Political theory, Evanston, v. 7, n. 1, p. 5-34, fev. 1979.

SILVANO, G. Vivere civile e Governo misto a Firenze nel Primo Cinquencento. Bologna: Patron Editore, 1990.

SKINNER, Quentin. As fundações do pensamento político moderno. São Paulo: Companhia das letras, 1996. . Maquiavel. São Paulo: Brasiliense, 1988.

STRAUSS, L. Penseé sur Maquiavel. Paris: Payot, 1982.

WALKER, L. J. The Discourses of Nicolò Machiavelli. London: Routledge \& Kegan Paul, 1950.

ZANCARINI, J.-C. Gli umori del corpo politico: "popolo" e "plebe" nelle opere di Machiavelli. In: 'La lingua e le lingue di Machiavelli' , Atti del Convegno Internazionale del studi, Torino, 2-4 dicembre de 1999. Firenze: Leo Olschki Editore, 2001, p. 61-70.

Recebido: 08/01/2019

Aprovado: 29/03/2019

Publicado: 13/05/2019 
